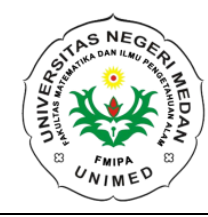

\author{
JURNAL EINSTEIN \\ Jurnal Hasil Penelitian Bindang Fisika \\ Available online http://jurnal.unimed.ac.id/2012/index.php/einsten \\ e-issn: $2407-747 x$, p-issn $2338-1981$
}

\title{
ANALISIS SIFAT MEKANIK KOMPON KARET DENGAN BAHAN PENGISI ABU TANDAN KOSONG KELAPA SAWIT
}

\author{
M.T.Saragih dan E.M.Ginting \\ Jurusan Fisika, Fakultas Matematika dan Ilmu Pengetahuan Alam, Universitas Negeri Medan, \\ Indonesia \\ soembayak@mhs.unimed.ac.id \\ Diterima September 2018; Disetujui Oktober 2018; Dipublikasikan November 2018
}

\begin{abstract}
ABSTRAK
Penelitian ini bertujuan untuk mengetahui sifat mekanik kompon dengan bahan pengisi Abu Tandan Kosong Kelapa Sawit (ATKKS) yang meliputi kekuatan tarik, perpanjangan putus dan kekerasan. Metode yang dilakukan adalah dengan cara mencampur dan menggiling nanopartikel ATKKS dengan karet SIR 20 hingga homogen dengan menggunakan open mill.Variasi komposisi bahan pengisi ATKKS yaitu 0, 2, 4, 6, dan 8 phr (part per hundred rubber). Analisis kekuatan tarik dan perpanjangan putus pada kompon diuji dengan menggunakan alat uji tarik Tensiometer, sedangkan kekerasan menggunakan Durometer. Komposisi kompon terbaik terdapat pada sampel dengan bahan pengisi ATKKS 8 phr dengan nilai kekuatan tarik sebesar 1,2 $\mathrm{MPa}$, nilai perpanjangan putus sebesar $120 \%$ dan nilai kekerasan sebesar 55 Shore A.
\end{abstract}

Kata Kunci : Kompon Karet, Abu Tandan Kosong Kelapa Sawit (ATKKS), Karet Alam

\section{PENDAHULUAN}

Kelapa sawit (Elaeisguineensis) adalah salah satu komoditi andalan Indonesia, khususnya Provinsi Sumatera Utara yang telah mengalami perkembangan demikian pesat. Selain produksi minyak kelapa sawit yang tinggi, produk samping atau limbah pabrik kelapa sawit yang dihasilkan juga tinggi. Dengan kondisi yang demikian itu sebenarnya banyak sekali manfaat yang dapat diperoleh untuk menciptakan kelapa sawit sebagai industri yang zero waste. Limbah menjadi pusat perhatian dunia dalam peningkatan perlindungan terhadap alam, maka berbagai teknologi telah dikembangkan untuk memanfaaatkan limbah tersebut. Setelah dilakukan proses pengolahan kelapa sawit, akhirnya menyisakan TKKS berkisar 20-23\% dari jumlah panen 1 ton Tandan Buah Segar (TBS) (Wardani dan Widiawati, 2015). TKKS adalah limbah terbesar berupa padatan dari industri pengolahan kelapa sawit. Secara fisik, TKKS mengandung berbagai macam serat dengan komposisi antara lain 41,30-46,50 \% selulosa, 25,30-33,80\% hemiselulosa dan 27,60-32,50\% lignin (Islami dan Sarwani, 2016). Pemanfaatan TKKS oleh Pabrik Kelapa Sawit (PKS) masih sangat terbatas. Sebagian besar PKS masih membakar TKKS dalam incinerator menjadi ATKKS.

ATKKS merupakan sisa pembakaran TKKS pada pengolahan kelapa sawit. ATKKS berpotensi untuk dikembangkan menjadi barang yang memiliki nilai guna yang tinggi jika dicampurkan dengan karet alam (Fuadi dan Pranoto, 2016) karena ATKKS menghasilkan serat kuat sebagai bahan pengisi dalam produk serat berkaret, di antaranya sarung tangan, jok mobil, matras dan papan komposit (Aulia, dkk., 2013). Analisa senyawa yang terkandung dalam ATKKS telah dilakukan oleh Husin, dkk (2011) 
dimana diperoleh $\mathrm{Fe}_{2} \mathrm{O}_{3}$ 0,2\%, $\mathrm{Na}_{2} \mathrm{O} 0,34 \%, \mathrm{MnO}$ 0,56\%, $\mathrm{MgO} 0,78 \%, \mathrm{P}_{2} \mathrm{O}_{5} 1,95 \%, \mathrm{Al}_{2} \mathrm{O}_{3}$ 13,87\%, $\mathrm{CaO} 18,20 \%$ dan $\mathrm{SiO}_{2} 58,60 \%$.

Matriks yang digunakan pada penelitian ini untuk menyatukan filler menjadi satu struktur komposit yaitu karet SIR 20. Karet alam memiliki karakteristik yang unik seperti kekuatan tinggi, fleksibilitas dan elastisitas yang tinggi (Roslim et al, 2012), sehingga menjadi salah satu bahan penting yang digunakan secara luas oleh karena kelembutan alaminya dan kemudahan pembentukannya. Akan tetapi, perlu ditambahkan zat aditif untuk memperbaiki sifatsifat alami yang tidak dikehendaki sehingga diperoleh suatu produk seperti yang diharapkan. Campuran antara karet, bahan pengisi dan bahan-bahan aditif tersebut dikenal dengan nama kompon (Alfa, 2005). Kelapa Sawit (ABKS) (Tambunan., 2017), silika dan $\mathrm{CaCO}_{3}$ (Rahmaniar, dkk.., 2014) dan arang cangkang sawit (Nuyah dan Rahmaniar, 2013; Nasution., 2015). Namun, bahan-bahan tersebut memiliki kelemahan yaitu dari segi ketersediaan dan cara pengolahannya yang memerlukan banyak waktu. Oleh karena itu, penggunaan selulosa dan lignin yang berasal dari TKKS sebagai bahan pengisi dapat mengatasi masalah-masalah tersebut karena jumlahnya yang lebih melimpah serta cara pengolahannya yang relatif lebih singkat (Aulia, dkk., 2013).

Penelitian tentang campuran ATKKS dengan karet alam telah dilakukan (Prendika., 2013) yang meneliti pengaruh penambahan bahan pengisi TKKS pada komposit termoplastik elastomer dari polipropilena dengan karet, (Setiawati, dkk., 2015) membuat komposit karet alam dan TKKS dengan variasi massa selulosa, (Shinoja et al, 2010) yang meneliti komposit serat kelapa sawit dan (Law et al, 2007) yang meneliti sifat morfologi dan kimia serat TKKS.

Penelitian ini bertujuan untuk mengetahui mengetahui sifat mekanik kompon dengan bahan pengisi ATKKS yang meliputi kekuatan tarik, perpanjangan putus dan kekerasan. Variasi komposisi bahan pengisi ATKKS yaitu 0, 2, 4, 6, dan 8 phr.

\section{METODE PENLITIAN}

\section{Bahan Penelitian}

Bahan yang diperlukan yaitu nanopartikel ATKKS ukuran 68,63 nm, karet SIR 20 produksi Pusat Penelitian Karet Sei Putih Sumatera Utara, Wax, Asam Stearat, ZnO, Sulfur, IPPD, TMTD dan MBTS.

\section{Alat Penelitian}

Alat yang digunakan yaitu Universal Testing Machine(UTM) untuk pengujian kekuatn tarik dan perpanjangan putus, pengujian kekerasan menggunakan Durometer dengan ASTM D.2240-15 dan pemotong Dumbbell.

\section{Pembuatan Kompon Karet}

1. Menimbang bahan-bahan kompon yaitu karet SIR 20, ATKKS, sulfur, Wax, ZnO, SA, IPPD, TMTD, MBTS dengan menggunakan neraca digital.

2. Setelah bahan-bahan ditimbang, karet SIR 20 dimasukkan ke dalam mesin open mill secara bertahap selama penggilingan hingga karet benar-benar homogen dan padat.

3. Proses pencampuran kompon dengan cara memotong dari ujung sisi gilingan, digulung lalu digiling kembali hingga homogen.

4. Kompon yang telah selesai dibuat dalam bentuk lembaran dikeluarkan dari gilingan dan dimasukkan ke dalam kantongan plastik dan diberi label sesuai dengan kode sampel, lalu didiamkan selama 24 jam.

5. Hasil cetakan dalam bentuk lembaran, kemudian dibuat sampel uji dengan menggunakan alat pemotong karet dumbbell, untuk sampel uji kekuatan tarik dibuat dengan standar ASTM D.412-16.

6. Tahap selanjutnya adalah karakterisasi sifat mekanik kompon karet, yang terdiri dari analisis kekuatan tarik, perpanjangan putus dan kekerasan.

Adapun formulasi kompon ditunjukkan dalam Tabel 1. dan Tabel 2. berikut. 
Tabel 1. Komposisi Campuran Bahan Formula Kompon Dengan Filler ATKKS dalam phr

\begin{tabular}{|c|c|c|c|c|c|}
\hline \multirow{2}{*}{ Bahan-Bahan } & \multicolumn{5}{|c|}{ Formula Kompon (phr) } \\
\cline { 2 - 6 } & $\mathrm{S}_{0}$ & $\mathrm{~S}_{1}$ & $\mathrm{~S}_{2}$ & $\mathrm{~S}_{3}$ & $\mathrm{~S}_{4}$ \\
\hline Karet SIR 20 & 100 & 98 & 96 & 94 & 92 \\
\hline Wax & 1,5 & 1,5 & 1,5 & 1,5 & 1,5 \\
\hline Filler & 0 & 2 & 4 & 6 & 8 \\
\hline ZnO & 5 & 5 & 5 & 5 & 5 \\
\hline SA & 2 & 2 & 2 & 2 & 2 \\
\hline Sulfur & 3 & 3 & 3 & 3 & 3 \\
\hline IPPD & 2 & 2 & 2 & 2 & 2 \\
\hline TMTD & 1,5 & 1,5 & 1,5 & 1,5 & 1,5 \\
\hline MBTS & 2,5 & 2,5 & 2,5 & 2,5 & 2,5 \\
\hline
\end{tabular}

Tabel 2. Komposisi Campuran Bahan Formula Kompon Dengan Filler ATKKS dalam gram

\begin{tabular}{|c|c|c|c|c|c|}
\hline \multirow{2}{*}{ Bahan } & \multicolumn{5}{|c|}{ Formula Kompon (gram) } \\
\cline { 2 - 6 } & \multicolumn{5}{|c|}{ ATKKS } \\
\hline & So $_{\mathbf{y}}$ & $\mathrm{S}_{1}$ & $\mathrm{~S}_{2}$ & $\mathrm{~S}_{\mathbf{3}}$ & S $_{4}$ \\
\hline $\begin{array}{c}\text { Karet } \\
\text { SIR 20 }\end{array}$ & 130 & 127,4 & 124,8 & 122,2 & 119,6 \\
\hline Wax & 1,95 & 1,95 & 1,95 & 1,95 & 1,95 \\
\hline Filler & 0 & 2,6 & 5,2 & 7,8 & 10,4 \\
\hline ZnO & 6,5 & 6,5 & 6,5 & 6,5 & 6,5 \\
\hline SA & 2,6 & 2,6 & 2,6 & 2,6 & 2,6 \\
\hline Sulfur & 3,9 & 3,9 & 3,9 & 3,9 & 3,9 \\
\hline IPPD & 2,6 & 2,6 & 2,6 & 2,6 & 2,6 \\
\hline TMTD & 1,95 & 1,95 & 1,95 & 1,95 & 1,95 \\
\hline MBTS & 3,25 & 3,25 & 3,25 & 3,25 & 3,25 \\
\hline
\end{tabular}

\section{HASIL DAN PEMBAHASAN}

Hasil pengujian sifat mekanis kompon karet menggunakan Universal Testing Machine (UTM) meliputi hasil kekuatan tarik dan perpanjangan putus dan kekerasan

\section{Kekuatan Tarik}

Pada hasil karakterisasi sifat kekuatan tarik kompon yang dilakukan dengan mesin uji mekanik UTM dengan standar ASTM D.412-16 diperoleh data kekuatan tarik pada Tabel 3 . berikut.
Tabel 3. Hasil Pengujian Kekuatan Tarik Kompon Karet

\begin{tabular}{cc}
\hline $\begin{array}{c}\text { Komposisi Filler } \\
\text { (phr) }\end{array}$ & Kekuatan Tarik (MPa) \\
\hline Tanpa Filler & 0.6 \\
2 & 1.4 \\
4 & 1.2 \\
6 & 1.4 \\
8 & 1.2 \\
\hline
\end{tabular}

Berikut ini grafik hubungan kekuatan tarik terhadap komposisi ATKKS dapat dilihat pada Gambar 1.

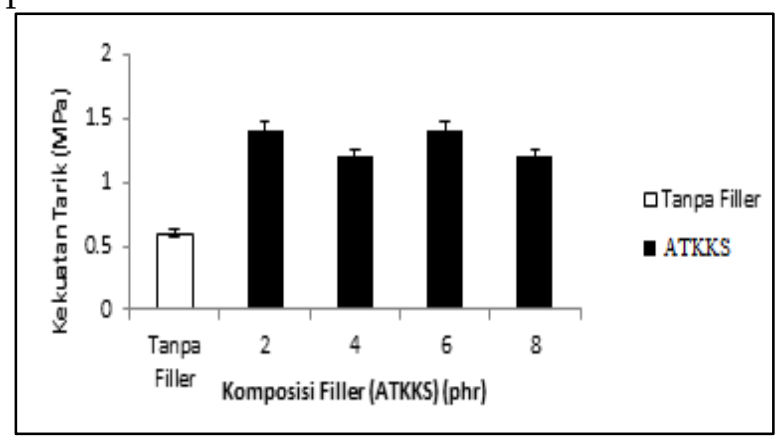

Gambar 1.Hubungan Kekuatan Tarik terhadap Komposisi ATKKS

Pada Gambar 1. di atas, nilai kekuatan tarik kompon karet dengan bahan pengisi ATKKS 2 phr mengalami peningkatan dibandingkan dengan nilai kekuatan tarik kompon karet tanpa bahan pengisi. Penambahan ATKKS 2 phr menambah kekuatan tarik karena adanya peningkatan ikatan kovalen dan hidrogen dengan grup $\mathrm{OH}$ dan oksigen dari grup karboksil yang masing-masing menambah ikatan antara pengisi dengan matriks karet alam (Ginting, dkk., 2014). Namun nilai kekuatan tarik cenderung berfluktuasi, sehingga tidak dapat ditemukan pengaruh penambahan ATKKS terhadap nilai kekuatan tarik kompon. Terjadinya hal tersebut kemungkinan disebabkan oleh karena waktu penggilingan kompon pada open mill kurang lama sehingga kompon belum tercampur secara homogen. Hasil penelitian yang telah dilakukan oleh (Kord, B., 2011) dan (Hildayati, 2009) menyatakan bahwa semakin banyaknya kandungan silika yang berakibat pada penurunan kekuatan tarik. Dari hasil pengujian kekuatan tarik kompon dapat disimpulkan bahwa nilai kuat tarik terbesar pada komposisi filler Carbon 
Black 6 phr dan 8 phr dengan nilai sebesar 1.8 $\mathrm{MPa}$.

\section{Perpanjangan Putus}

Perpanjangan putus adalah penambahan panjang suatu potongan uji bila diregangkan sampai putus, dinyatakan dengan $\%$ dari panjang potongan uji sebelum diregangkan. Pada hasil karakterisasi sifat perpanjangan putus yang dilakukan dengan mesin uji mekanik mekanik UTM dengan standar ASTM D.412-16 diperoleh data perpanjangan putus pada Tabel 4 . berikut.

Tabel 4. Hasil Pengujian Perpanjangan Putus Kompon Karet

\begin{tabular}{cc}
\hline $\begin{array}{c}\text { Komposisi Filler } \\
\text { (phr) }\end{array}$ & $\begin{array}{c}\text { Perpanjangan Putus (\%) } \\
\text { (ATKKS) }\end{array}$ \\
\hline Tanpa Filler & 100 \\
2 & 120 \\
4 & 110 \\
6 & 120 \\
8 & 100 \\
\hline
\end{tabular}

Berikut ini grafik hubungan perpanjangan putus terhadap komposisi ATKKS dapat dilihat pada Gambar 2.

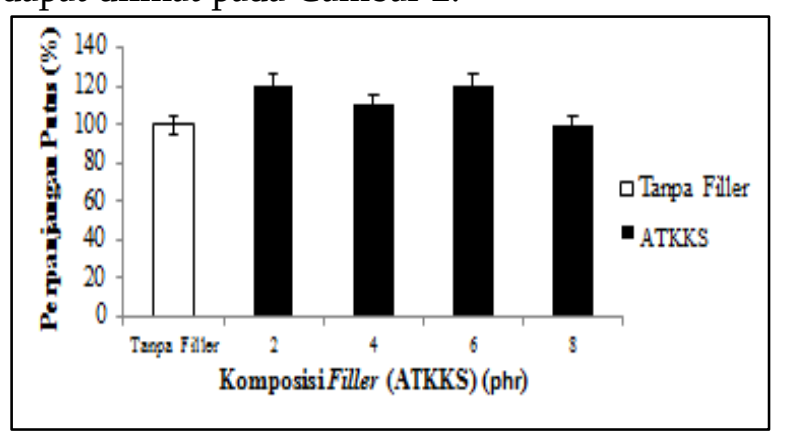

Gambar 2. Hubungan Perpanjangan Putus Terhadap Komposisi ATKKS

Perpanjangan putus merupakan salah satu sifat fisika barang jadi karet untuk mengetahui sifat elastisitas dari produk yang akan menunjukkan sampai seberapa produk yang berbentuk ring dapat diregangkan dengan tepat pada tempatnya. Jika kemulurannya terlalu besar maka produk akan mudah ditarik sehingga pada pemakaiannya tidak dapat dikencangkan dengan tepat. Nilai perpanjangan putus kompon karet dengan bahan pengisi ATKKS mengalami fluktuasi dengan nilai tertinggi pada komposisi filler 2 phr dan 6 phr yaitu $120 \%$ dibandingkan dengan nilai perpanjangan putus kompon karet tanpa bahan pengisi. Hal itu disebabkan karena penggilingan kompon pada mesin open mill kurang lama sehingga bahan tidak tercampur secara homogen dan sempurna. Dari hasil uji perpanjangan putus berbahan pengisi ATKKS dengan komposisi filler 8 phr memiliki sifat yang lebih kaku karena mengandung silika yang bersifat kaku atau keras. Sehingga kompon yang dihasilkan sulit untuk diregangkan maka dihasilkan nilai perpanjangan putus yang rendah. Nilai perpanjangan putus berbanding terbalik dengan nilai kekuatan tarik dan peningkatan nilai perpanjangan putus berbanding lurus dengan peningkatan kadar abu sawit yang digunakan (Nanda, dkk., 2014). Berdasarkan nilai perpanjangan putus yang diperoleh maka kompon ini dapat diaplikasikan untuk produk sarung tangan sesuai satandar SNI 16-2622-2002 dan SNI 16-2623-2002.

\section{Kekerasan}

Kekerasan merupakan sifat yang sangat mempengaruhi penampilan dan ketahanan barang jadi karet. Pada hasil karakterisasi sifat kekerasan yang dilakukan dengan mesin uji mekanik dengan sampel Dumbbell ASTM D.2240-15 diperoleh data kekerasan pada Tabel 5. berikut.

Tabel 5. Hasil Pengujian Kekerasan Kompon

\begin{tabular}{cc}
\multicolumn{2}{c}{ Karet } \\
\hline $\begin{array}{c}\text { Komposisi Filler } \\
(\text { phr })\end{array}$ & $\begin{array}{c}\text { Kekerasan (Shore A) } \\
(\text { ATKKS })\end{array}$ \\
\hline Tanpa Filler & 50 \\
2 & 50 \\
4 & 53 \\
6 & 53 \\
8 & 55 \\
\hline
\end{tabular}

Berikut ini grafik hubungan kekerasan terhadap komposisi ATKKS dapat dilihat pada Gambar 3. 


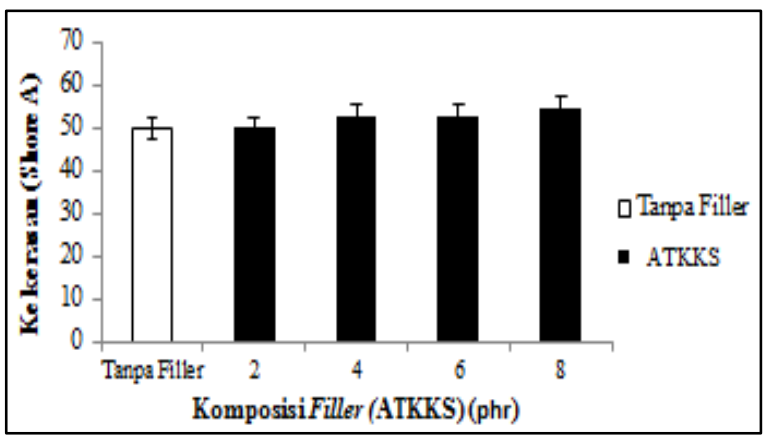

Gambar 2. Hubungan Kekerasan Terhadap Komposisi ATKKS

Nilai kekerasan kompon karet dengan bahan pengisi ATKKS mengalami peningkatan dibandingkan dengan nilai kekerasan kompon karet tanpa bahan pengisi. Peningkatan nilai kekerasan kompon karet adalah disebabkan karena kandungan silika pada ATKKS yang lebih cenderung meningkatkan kekerasan dan dapat memberikan perbaikan sifat fisik karet (Nanda, dkk., 2014). Semakin besar komposisi $\mathrm{SiO}_{2}$ didalam matriks, maka sifat yang dihasilkan semakin keras. Hal ini menunjukkan nilai kekerasan yang lebih baik dari penelitian Hildayati (2009), dimana dalam penelitian ini digunakan bubuk silika sebagai penguat matriks karet alam yaitu 36,67 Shore A. Nilai kekerasan tertinggi yang diperoleh pada penelitian ini sebesar 55 Shore A yaitu pada sampel dengan variasi ATKKS 8 phr. Dengan nilai kekerasan seperti ini dapat digunakan untuk proses pembuatan bahan jadi karet seperti sarung tangan sesuai satandar SNI 16-2622-2002 dan SNI 162623-2002.

\section{KESIMPULAN DAN SARAN}

Komposisi terbaik kompon karet dengan bahan pengisi ATKKS yaitu $8 \mathrm{phr}$ menunjukkan kekuatan tarik sebesar $1.2 \mathrm{MPa}$, perpanjangan putus $100 \%$ dan kekerasan sebesar 55 Shore A. Dari hasil analisis sifat mekanik yang diperoleh, maka penelitian ini dapat diaplikasikan untuk proses pembuatan sarung tangan (SNI 16-26222002 dan SNI 16-2623-2002).

\section{DAFTAR PUSTAKA}

Alfa, A. A., (2005), Bahan Kimia Untuk Kompon Karet-Kursus Teknologi Barang Jadi Karet Padat, Bogor: Balai Besar Penelitian Teknologi Karet Bogor Ash
And Deposit Characteristics From Oil Palm Empty Fruit Bunch (EFB) Firing With Kaolin Additive In A Pilot Scale Grate Fired Combustor, Elsevier, 115 : 182-191.

Aulia, F., Morpongahtun., dan Gea, S., (2013), Studi Penyediaan Nanokristal Selulosa Dari Tandan Kosong Sawit (TKS), Jurnal Saintia Kimia, 1 (2).

Fuadi, A. M., dan Pranoto, H., (2016), Pemanfaatan Limbah Tandan Kosong Kelapa Sawit Sebagai Bahan Baku Pembuatan Glukosa, Jurnal Chemica. 3 (1) : 1-5.

Ginting, E. M., Bukit, N., Muliani., and Frida, E.; Mechanical Properties And Morphology Natural Rubber Blend With Bentonit And Carbon Black, IPST 2014.

Hildayati., Triwikantoro., Faisal, H., dan Sudirman., (2009), Sintesis dan Karakterisasi Bahan Komposit Karet Alam-Silika, Seminar Nasional Pascasarjana IX - ITS, 12 Agustus 2009, Surabaya

Husin, H., Mahidin dan Marwan., (2011), Studi Katalis Abu Sabut Kelapa, Abu Tandan Sawit, dan K2CO3 Konversi Minyak Jarak Menjadi Bodiesel, Reaktor, 13 (4) : 254-261.

Islami, H, dan Sarwani, M., (2016), Potensi Limbah Tandan Kosong Kelapa Sawit dan Sekam Padi Sebagai Bahan Alternatif Pembuatan Kertas Menggunakan Proses Soda, Prosiding SeminarNasional Industri Kimia dan Sumber Daya Alam.

Kord, B., (2011), Nanofiller Reinforcement Effects on The Thermal, Dynamic Mechanical, and Morphological Behavior of HDPE/Rice Husk Flour Composites, BioResources, 6 (2) : 13511358.

Law, K. N., Daud, W, R. W., and Ghazali, A., (2007), Morpgological and Chemical Nature of Fiber Strands of Oil Palm Empty - Fruit - Bunch (OPEFB), Bioresources, 2 (3) : 351-362.

Nanda, H N., Bahruddin., dan Fadli, ahmad., (2014), Pengaruh Maleated Natural 
Rubber Terhadap Morfologi Dan

Sifat Thermoset Rubber Dengan Filler

Abu Sawit - Carbon

Black,JOM FTEKNIK,1(2) : 1-13.

Nuyah dan Rahmaniar., (2013), Pembuatan

Kompon Karet Dengan Bahan Pengisi

Arang Cangkang Sawit, Dinamika

Penelitian Industri, 24 (2) : 114-121

Prendika., (2013), Pengaruh Penambahan

Pengisi Tandan Kosong Kelapa Sawit

Pada Komposit Termoplastik Elastomer Dari Polipropilena-Karet Ethylene Propylene Diene Monomer, Skripsi, FMIPA, USU, Medan.

Rahmaniar., Rejo, A., Priyanto, G., Hamzah, B., (2014), Karakteristik Kompon Karet Dengan Menggunakan Bahan Pewarna dan Bahan Pengisi dari Bahan Alami, Prosiding Seminar Nasional Kulit, Karet, dan Plastik ke-3 Yogyakarta.

Roslim, R., Hashim, Y. A., and Angurio, P. T., (2012), Natural Latex Foam, Journal of Engineering Science, 8 : 15-27.

Setiawati, S., Sitorus, B., dan Malino, M. B., (2015), Sintesis dan Karakterisasi Komposit Karet Alam-Selulosa Dari Tandan Kosong Kelapa Sawit Dengan Variasi Massa Selulosa, JKK,4 (3) : 6572.

Shinoj, S., Visvanathan, R., Panigrahi, S., Kochubabu, M., (2011), Oil Palm Fiber (OPF) And Its Composites: A Review. Industrial Crops And Products, 33 : 722.

Tambunan., (2017), Pembuatan Dan Karakterisasi Kompon Karet Dengan Filler Nanopartikel Abu Boiler Kelapa Sawit dan Carbon Black, Skripsi, FMIPA, UNIMED, Medan.

Wardani, A. P. K., dan Widiawati, D., (2015), Pemanfaatan Tandan Kelapa Sawit Sebagai Material Tekstil Dengan Pewarna Alam Untuk Produk Kriya, Jurnal Tingkat Sarjana Bidang Seni Rupa dan Desain, (1) : 1-10. 